\title{
The Antelope and the Hyena: An Urgent Warning Against The New Socialism
}

\author{
Michael A. Milton, $\mathrm{PhD}^{1,2}$ \\ ${ }^{1}$ Erskine Theological Seminary \\ ${ }^{2}$ D. James Kennedy Institute of Reformed Leadership
}

February 3, 2022

\begin{abstract}
Americans, particularly younger adult generations, evidence an increasing fascination with socialism. This paper examines the Cold War realities, offering a narrative and personal experience to provide an overview of the consequences of adopting that system and ideology defeated by the English-speaking western nations in 1989-1991. Special attention is given to the People's Socialist Republic of Albania as an example of socialism. This paper examines the Cold War realities, offering a narrative and personal experience to provide an overview of the consequences of adopting that system and ideology defeated by the English-speaking western nations in 1989-1991. Special attention is given to the People's Socialist Republic of Albania as an example.
\end{abstract}

\section{Introduction}

Are we trying to become the very thing that we defeated?

I will never forget what I witnessed in the Cold War - the War that was not a war - and I could never imagine any nation wanting to build a house out of ashes.

From 1947 until 1991, the United States, Great Britain, and the British Commonwealth nations (along with the war-weakened Western European countries), still recovering from the unimaginable sacrifices made to defeat Nazism and Fascism, faced a new menace, one that had been strengthening on the blood of its people since October 1917 (the Russian Revolution). ${ }^{[1]}$ Thus, the (primarily) Anglo-American civilizations were called upon to defend human liberty against the encroaching dark and evil night of Socialist and Communist regimes: the Soviet Union and Communist China and their puppet states. George Orwell coined the term for the global post-WWII crisis: "The Cold War." ${ }^{[2]}$ The Austrian-British economist, F.A. Hayek (1899-1992), predicted that centralized state powers were, in fact, powers of darkness that would lead to prison states and utter poverty. ${ }^{[3]}$ Noting that wartime realities forced emergency consolidation of powers reserved for the governed, Hayek warned the West against politically expedient temptations to keep and assume even more centralized controls. F.A. Hayek's classic book of warning, The Road to Serfdom, was released in March 1944. The London School of Economics (LSE) scholar leveraged a life of research and writing to issue a dire warning: viz., nations that seize power from the people during emergencies, like WWII, had to return those emergency powers to the People.

Centralization of governance (and, in some cases, a suspension of rights) was necessary to support the national war efforts against Nazi Germany and Imperial Japan. However, Hayek warned that when formidable interests get a taste of the intoxicating liqueur of power, find it difficult to "return" self-governance rights 
to the People. Thus, the West began the struggle against Sino-Soviet Communism and the Cold War while striving against domestic political parties, e.g., the British Labour Party and the Democratic party in the United States, that introduced Socialism within the great Western nations. It was an incredible period of history as Socialist-Communist states and Western Allies conducted a complex geopolitical chess match under the threat of nuclear annihilation. The Communists were clear in their end goal: world domination. The US and Britain were equally clear about defending liberty but had to do so with one hand tied behind their backs (viz., leftist movements at work within both countries). ${ }^{[4]}$

Leaders on all sides assured the People that the Cold War was not a war. It was a hard pill to swallow for the more than seven million Cold War grieving survivors. Dr. Joshua Goldstein, in the Journal of Foreign Policy, documented close to 180,000 lives lost each year from 1950 to 1989 due to the "conflicts," "crises," and "skirmishes." ${ }^{[5]}$ If the Cold War was just a "long peace," as has been suggested, it certainly was a bloodstained peace with all the marks of war. However, The War that wasn't a war was not only a day-to-day fear of the Apocalypse but a period of enormous societal disruption; and that fact leads one back to the agitators from within. As Dr. Paul Kengor has documented with irrefutable research, the Soviets "duped" American liberal politicians throughout the Cold War. ${ }^{[6]}$ Covert operatives from the Soviet Union carried out successful disinformation campaigns by infiltrating Western institutions. Bastions of Western Civilization such as the university, the media, government, and even Christian denominations, were weakened by a foolish fascination with Marxism, French deconstructionist social theories, and anti-Christian philosophers (such as the Postmodernist professor Michael Foucault). Popular influencers like Hollywood, the Stage, and the music industry quickly caught up with their higher art and letters comrades, and merrily, unthinkingly, carried the Socialist messaging to America, Thus, with our institutions emaciated, our economy in shambles, and our People disrespecting law enforcement, the military, and most any authority, America became a wounded eagle, down but not out, hunted by the ferocious Moscow bear. To quote one Cold War scholar, the West suffered from a "failure of ideological cohesion.. ${ }^{[7]}$ Meanwhile, The Soviets and their satellite states persecuted Christians and other groups, racking up murders in the millions. ${ }^{[8]}$

Many of us in America today lived through those days. I served as a Top-Secret Naval Intelligence interpreter in the 1970s. Our Naval Security Group gathered intelligence, sifted through propaganda, and interpreted data from the Communist enemies worldwide, 24-7, 365 days a year, in the air, on land and sea, deep beneath the ocean surface, and even in outer space.

My point is not to repeat a portion of my curriculum vitae. I share this background with you because I know, personally, what Socialism and Communism can do to a nation. Socialism-Communism seeks to replace GOD with Statism; self-reliance and human dignity with governmental dependence; and representative government with totalitarianism. The Socialist State seeks to replace meritocracy with identity politics, the American Puritan work ethic with equal outcomes, upward mobility with elitism, the family with the collective, the university with indoctrination camps, and the protection of the vulnerable with the survival of the fittest. The Socialists seize intellectual pressure points in culture. Then, having deconstructed and desecrated the older order, they wait. The new socialists wait until events converge to create a decisive moment, a turning point. "Never let a good crisis go to waste" is an accurate if not detestable and insensitive philosophy worthy of the most loathsome beasts. ${ }^{[9]}$ "Emergency measures" remain Socialism's main play for seizing permanent power.

The laughing hyena is an appropriate example of how Socialism ascends to dominance, even in the presence of ostensibly greater creatures.

\section{The Antelope and the Hyenas}

Trailing a weakened antelope, a savage clan of spotted hyenas slobber, snarl, and scream, but wait. The maniacal monsters wait for a crisis. With a growing sense of dread, a weary, aging antelope is aware of his stalkers. The distraction paves a deadly path for the noble creature. Indeed, the antelope under duress makes one wrong move, then another. He takes chances. The antelope is resilient, and he knows he can ordinarily 
defeat the demented marauders. However, the sum of his small mistakes equates to a fatal conclusion. The mighty Lord Derby Eland antelope, disturbed by the growing threat of the pillaging predators, get bogged down in the mud while seeking shelter in a shallow river. This is what the maddened monsters have been waiting for: a crisis of opportunity. Several of the faster hyenas lunge to tear at the rump of the immobilized antelope. The impressive two feet of twisted antlers are daunting weapons of the wild. When his head is down and in fighting stance, a one-ton male charge at twenty-five miles per hour. Even imperiled, the great eland is dangerous. Several hyenas lay dead, gorged and stomped by the massive animal. However, the remaining hyaenas are unmoved. They know: "We have more than enough to get the job done." The vicious rabble encircles the prey ever closer. Their numbers grow. The piercing yelps reverberate through the wild like an invitation to the impending blood games at the Colosseum. Other predatory species, eager to join a bloodfeast, now, arrive. The wait intensifies. The younger male warriors are quivering with nervous anticipation to ambush the compromised six hundred pounds of flesh in the mud. "Bel," the prince of the spotted hyenas, calms the quivering cackle of hyenas, "Patience my lads, patience . . ." says the Alpha-male. "For what?" A young lieutenant asks. The devilish older beast answers the eager underling with the wisdom of the Serengeti: "For the inevitable tipping point in the game," says the conniving conquistador: "We wait for that moment when our incremental, smaller attacks escalate to a crescendo, and then, my boy - then - there is no way out for the once-mighty hind! A crisis, catastrophe, or emergency will hit. There is always a crisis! We will use whatever upheaval that fate sends us as the cover for our decisive, final, and fatal take-over!" Then, the beast has lost, and the fool's flesh is ours!" This strategic postponement of hostilities may last through the day. As the shadows of darkness approach, the ravenous hyaenas are ordered to strike intermittently. The disease-laden dogs and hyaenas howl in a dizzying cacophony of hellish, eardrum-splitting noises, like a warring tribe shrieking, with incessant sounds of drums pounding, evil laughter, and screams from the netherworld. The hyaenas are now drunk on anticipation. Suddenly, the assurances of the Alpha jackal are justified. Suddenly, a lioness appears. She strikes at the antelope. Then, another. This is what the hyenas and jackals have been waiting for: a bifurcation of time. The equilibrium of norms, chipped away by smaller attacks, is, at that moment, upended by a singular event. This is the long-awaited apocalyptic tipping point from which there can be no return. This is the midnight hour, the climactic moment when the lazier afternoon hours are recognized for what they were: not a reprieve from the attacks, but the final countdown to sudden death. The act only needed one crisis, one emergency, one spark, one pandemic of mayhem, to allow the antelope to fall to the dominance of the demonic predators.

We need not recount the gruesome events that followed. It is enough to say: once the crisis appeared the catastrophe was inevitable. By morning the scattered bones of the once magnificent antelope are strewn as silent tombstones in a battlefield. A few younger antelopes approach the devastating scene. They sniff at the scene of death. It is alarming, and, for a second, even confusing if not foreboding. However, the strong young antelopes are healthy, free, and easily distracted by the promise of youth. They move on to graze without further thought of the witness of history. The yearlings have fooled themselves with the dependable lie of history: "It could never happen again."

And shall we, too, move past the ominous reminders of the Cold War?

When I see the increasingly dangerous consolidation of power by one party in Washington - not by democratic processes but by a confederacy of political machinations - the escalation of lawlessness in the land, unbridled racism that incites the lower instincts to retreat to tribes, and the replacement of national identity around the ideas of the Constitution with the prejudicial interests of groups, the immorality in so-called entertainment, the widespread naïveté and uncritical acceptance of poisonous new cultural norms, then, my mind returns to the Cold War. I see the bones of a struggle that left millions dead, and I cannot pass unmoved and uninterested.

Mercifully, the Lord gave us a Ronald Reagan, a Margaret Thatcher, and John Paul II, along with Rev. Billy Graham, and many others, who not only recognized the threats, but named them, challenged them, and, by God's grace, defeated them. ${ }^{[10]}$ Some say that the Cold War ended when the Berlin Wall came down. Others recognize that there was an earthquake event that sent a fault line running through the length of the Berlin 
Wall and split the Iron Curtain.

In June 1979 John Paul II touched down in Poland. Against every order, the Pontiff conducted a great Communion Service. The people even saw the secret police abandoning their shadows and taking their place in the line to receive the Bread and the Cup. ${ }^{[1]}$

The late Dr. Lee Edwards, the renowned American historian, was unequivocal in his assessment: "The Pope's historic pilgrimage set in motion 'a revolution of the spirit' that resulted - a mere decade later -in the collapse of communism in eastern and central Europe." ${ }^{[12]}$

I was there as Communism collapsed - not in Poland or East Germany,- -but the most Stalinist-Communist regime on earth: Albania.

\section{The Miracle of the Parish in the Woods}

Albania was the last Communist nation to break free from the diabolical grip of totalitarianism. In 1991 I was there, preaching through the country and serving as a journalist for World Magazine. One evening, my Albanian host, a young man who was a student at university, asked me to join him at Skanderbeg Square. He informed me that there would be a significant student gathering in that main public space in the capital city - a demonstration to celebrate freedom. "We want you to preach the Gospel." So, that night, we gathered with hundreds of students in Skanderbeg Square. The liberty-loving young people had toppled the 30-foottall bronze statue of the infamous and ruthless dictator, Enver Hoxha (1908-1985; pronounced "Ho'-Jah"), in February $1991{ }^{13}$ The students had removed the disgraced figure to a location at the University of Tirana. I must only assume that the statue's head came loose from the body and was brought to the square (or another dictator's head was available). For that unforgettable night, I preached the Gospel of Jesus Christ to Skanderbeg Square's masses from atop the severed metallic head of a dictator who vowed to wipe out Christianity once and for all time. I preached a message on true freedom in Christ from whom flows all other liberties in life.

The following day, in the hotel (a ramshackle turn-of-the-century room with water available, "When the shepherd boy can fix pump at the river"), I conversed with a Roman Catholic Bishop and an Albanian priest. The two Christian clerics were seated next to me, having coffee. The Bishop recognized me from the night before, at Skanderbeg Square. He leaned over towards my table, smiling and speaking English in a heavy native Italian accent, said, "Pastor, thank you for your message last night." I thanked him for his encouragement. He smiled and continued. "I want to introduce you to a great Christian hero." I turned my interest to an unusually thin, middle-aged man, wearing a Roman collar, and seated across from the Bishop. His face was noble though his cheeks seemed hollowed by disease or hunger, or, perhaps, both. Yet, rather than diminish his overall countenance, the obvious suffering that he had borne added to the depth of his presence. The priest's deep-set eyes made shadows in the excess skin wrinkled beneath. Oddly, the shadows served to paradoxically highlight his sparkling eyes of faded cornflower. There was sunlight in the dark recesses of pain. There was joy. There was suffering, and one attribute did not cancel the other, but, instead, formed the full measure of this man's countenance. His head was shaved clean, though I noticed he had not shaved that morning. "Mirë dita, Pastor!" ("Good day, Pastor) the priest smiled and radiated what I could only describe as sincerity, and contentment. "I am *Father John," he said. ${ }^{[14]}$ The priest's unbridled smile revealed more gum than tooth. The Bishop asked the Albanian priest to stand and raise his shirt to reveal his bareback. Father John moved sprightly at the bishop's behest, though it appears to me that the priest moved at great personal cost. The priest stood with an apparent favoring of one leg over the other, crippled by force of some brutish power. He looked, with modesty, to see if there were others around. Seeing none, he raised his arms backward, across his shoulders, to hoist his frayed and fading black clerical shirt from oversized slacks held in place by a piece of a leather leash. As Father John raised the shirt, gingerly, as if to minimize an incredible pain, it suddenly occurred to me that the scene was like a dramatic lifting of curtains at a county fair, to reveal a scene of horror. To be clear, the drama of the unveiling was not 
contrived, but inherent. Both the bishop and the priest looked at me to see my reaction. They knew from experience that $I$ would experience a reaction.

I can never banish the gruesome visage that I witnessed that day. The conception before me was encoded in my brain as explicit memory. As such, the vision was seared through the thin membrane separating matter and spirit. The sight metastasized into emotion and became an experience. It is as disturbing at this moment as when I saw it on that summer morning in 1991. The flesh on the priest's emaciated back looked like a veritable mountain range of lesions, welts, and wounds that had, over time, melded together to create a grim testimony to inhumanity. I was invited to observe his wounds more carefully - which I took as somewhat odd but followed the guidance. So, I continued to gaze in horror at Father John's mangled flesh. The Bishop, wanting me to experience the depth of suffering of the priest before speaking, at last, spoke.

You see this, Pastor? Is this not horrible? I will tell you what happened. I will tell you about 'Utopia' in the Peoples Socialist State of Albania! This good man was in a hard labor prison for five years. His crime? Father John had been caught by the secret police baptizing children in an underground church in Albania's northern mountainous regions. What you see, Pastor, is the price of following God in a godless system.

The People's Socialist Republic of Albania, officially atheist by the constitution, having purged the land of clergy in 1968 - I have a book of photographs of the hangings in my study - considered expressions of faith in God as a class of crime most seditious. The Socialists believed, "You cannot love God and the State." So, the Communists got rid of God, or so they supposed.

There was an uninterrupted silence as I looked upon Father John's back as if to honor the presence of one who had suffered for Christ. The Bishop fixed his eyes upon mine as if to demand silence at the sight, and, to seal his words and sear my view into my consciousness. At a moment he calculated to be unbearable to see anymore, the bishop turned to the priest, and instructed him in Albanian, "Tell this Presbyterian minister about how God used that time." The priest with his arms turned backward, holding his black clerical shirt to his shoulders, his naked back of fused flesh fully exposed, spoke to me in his native northern dialect: "The Communist guards beat me because I would not deny my Savior, the Lord Jesus Christ. I love Him more today than I have ever loved Him. God was at work, Pastor. You must believe me! I know I look terrible, but God is in this!"

As I listened, my eyes filled with tears. I tried to speak, but the wounds were to me a holy thing, a place where God dwelt. I was in awe even as Isaiah before the Lord. I heard the Lord speak in His Word to my spirit, "This is My body ..." (Luke 22:19) I recognized the lacerated flesh as reminders of the crucified and risen Christ. I sensed the presence of the holy: "But the LORD is in His holy temple. Let all the earth keep silence before Him" (Habakkuk 2:20 NKJV).

"Pastor ..." the Catholic bishop spoke as if he were a psychologist bringing me out of a hypnotic state. "Pastor, I know it is hard to see. Can you believe this?" I couldn't. The level of hatred of God and the depth of faith in God were juxtaposed and intersecting at the same time. At first, the encounter was difficult to process. But there it was. Father John, still presenting his wounds, spoke matter-of-factly and without any sign of emotion as if he had cried so often that he had depleted his tears. Still gazing upon the mutilated soft tissue covering unseen bruises and breaks, I heard this Christian shepherd speak once more, softly, without remorse or resentment, as he expressed theological reflection on the persecution:

"God was in the prison with me. You see, the guards were changed-out every few weeks. The sadistic ritual became too gruesome for only one man. Pastor, you must understand: I do not hold them accountable. I forgave them as they carried out their orders from that 'Beast,' the Socialist State. I want to tell you of a miracle. Pastor, some of the guards that lashed me and demanded that I renounce Jesus Christ became Christians. Some would even show up to perform their ghastly duty and only pretend to whack me. Then, those guards would gather with the poor prisoners - our once-strong Albanian men who could barely walk from the endless hours, days, months, and years of such hard labor, our women who suffered that kind of indignity and 
inhumanity that only our precious ladies and girls can know; and the little ones, with their sad eyes looking out from malnourished faces; looking at the suffering but not seeing the reason, unable to play, and unable to laugh. Yet, those same people welcomed the new converts to Christ. Together, we would assemble in my secret services in the forest. Ät that sentence, the priest, heretofore unbreakable, began to weep. "Oh, I miss them so: my parish in the woods." ${ }^{[15]}$

Like many Americans, Canadians, British, Western Europeans, and others, I have watched and listened to the voices of those seizing power by all necessary means, discrediting — "canceling" — any voice of dissent and requiring that the population not only do as they say but also believe what they believe. In Romans 1:18-32, St. Paul's description of the downward cycle of unbelief, the normalizing and codification of sin is the final ring of the Inferno of atheism (Vv. 28-32 in NASB):

And just as they did not see fit to acknowledge God any longer, God gave them over to a depraved mind, to do those things which are not proper, being filled with all unrighteousness, wickedness, greed, evil; full of envy, murder, strife, deceit, malice; they are gossips, slanderers, haters of God, insolent, arrogant, boastful, inventors of evil, disobedient to parents, without understanding, untrustworthy, unloving, unmerciful; and although they know the ordinance of God, that those who practice such things are worthy of death, they not only do the same, but also give hearty approval to those who practice them.

\section{Conclusion}

The president of the United States promised "unity." ${ }^{[6]}$ Yet, the furiously busy agenda unfolding before our eyes looks more like "uniformity." ${ }^{[17]}$ Unity is an aromatic virtue cultivated in the enriched soil of love and hope. Uniformity is the work of a legion of diabolical vandals of human liberty, with fascist goals erupting from the underworld. Uniformitarianism demands a ruthless agenda to forcefully silence all critics, carefully reeducate all others (so that the party line is protected), and ruthlessly centralize all powers.

I sense jackals and hyaenas in our midst. The bleached bones of fallen antelopes are scattered across human history. The great Eagle is in danger. Apathy and immorality, mixed with the incessant, mind-numbing, soul-searing cult of entertainment, and the Mad-hatter's world of Postmodernism, a Foucault-induced antiChristian mindset that deconstructs every sacred idea and replaces it with nonsensical words and imaginary concepts. ${ }^{[18]}$ Up is down. Down is up. Women are men. Men are women. Children are objects. Right is wrong and wrong is right. Only power and control remain free from deconstruction. For we must understand: Power and control are the currencies of the Socialist State.

But there is still the Lion - the Lion of Judah, the Lamb of God who takes away the sins of the world. He lives. He is, to borrow from Lewis, "on the move." He is more powerful than all of the jackals and hyenas in the world. He has shown that each time the beast has sought to devour His people He arrives. As with His arrival at Lazarus' funeral, He appears in His own time, and for His own purposes (John 11:5-7). He uses the very things which seek to destroy His kingdom to become the paradoxical power that destroys the enemies. It is always only a matter of time.

I, for one, would prefer the wounds from being beaten daily for telling the truth rather than to bow to the Beast and endure the eternal shame of living a lie. For, mark my words, the day will come when the Socialist State that is now being constructed in our country will fall to the ground, toppled by the masses who were denied their God-given right to "life, liberty, and the pursuit of happiness." The mighty Lion will roar from the holy mountain, His voice reverberating across the plains of time, "And ye shall know the truth, and the truth shall make you free" (John 8:32).

Out of the ruins of another crumbled wall will arise the great bald eagle, his wings fully extended in renewed strength, soaring freely, a heavenly sign in the skies, above the new growth on fruited plains; and landing with watchful eyes o'er that city on a hill. 


\section{BIBLIOGRAPHY}

Bottery, Mike. 1998. Professionals and Policy: Management Strategy in a Competitive World: $\quad$ Psychology Press.

-. 1999. "Education under the New Modernisers: An Agenda for Centralisation, Illiberalism and Inequality?" Cambridge Journal of Education 29, no. 1 (1999/03/01): 103-120. Cambridge Journal of Education. https://dx.doi.org/10.1080/0305764990290108.

Drábek, Jan. 2005. "Report from Albania. A Former Ambassador Finds Both Hope and Despair in

Albania." The New Presence, no. 3: 37-37. The New Presence.

Dunst, A. 2016. Madness in Cold War America: Mad America: Taylor \& Francis. https://books.google.com/books?id=JTQlDwAAQBAJ

Edwards, Lee. 2005. "John Paul Ii: Winning the Cold War." Heritage Foundation.

Farr, Thomas F. 2009. "Cold War Religion." First Things, no. 194: 47. First Things.

Gaddis, John Lewis. 2006. The Cold War: A New History: Penguin.

Goldstein, Joshua S. 2011. "Think Again: War." Foreign Policy 188: 1-9. Foreign Policy.

Hayek, Friedrich August. 2001. The Road to Serfdom: Psychology Press.

Kengor, Paul. 2006. The Crusader: Ronald Reagan and the Fall of Communism: Reagan Books.

—. 2007. "Ronald Reagan's Faith and Attack on Soviet Communism." In Religion and the American Presidency, 175-190: Springer. Religion and the American Presidency.

-. 2012. The Communist: Simon and Schuster.

- 2014. Dupes: How America's Adversaries Have Manipulated Progressives for a Century: Open Road Media.

-. 2017. A Pope and a President: John Paul Ii, Ronald Reagan, and the Extraordinary Untold Story of the 20th Century: Open Road Media.

McManus, Mike. 2005. "How Pope John Paul Fought Communism - by Mike Mcmanus | Virtueonline the Voice for Global Orthodox Anglicanism." Virtue Online. Accessed April 12, 2021. Form of Item. https: //virtueonline.org/how-pope-john-paul-fought-communism-mike-mcmanus .

Milton, Michael A. 2013. "What Ronald Reagan's Legacy Can Teach Us Today About Religious Liberty." Faith for Living, Inc., 4/17.

Orwell, George. 1945. "You and the Atomic Bomb." the Tribune 19: 1961.

Preston, Andrew. 2012. Faith and War: How Christians Debated the Cold and Vietnam Wars: Taylor \& Francis.

Schlesinger, Arthur. 1967. "Origins of the Cold War." Foreign Affairs 46, no. 1: 22-52. Foreign Affairs.

Teles, Steven M. 2016. "20. How the Progressives Became the Tea Party's Mortal Enemy." In The Progressives' Century, 453-477. New Haven: Yale University Press. The Progressives' Century.

Wolfe, CJ. 2011. "Lessons from the Friendship of Jacques Maritain with Saul Alinsky." Catholic Social Science Review 16: 229-240. Catholic Social Science Review.

Wurmbrand, Richard. 2017. Tortured for Christ: David C Cook. 


\section{Endnotes}

[1] George Orwell, "You and the Atomic Bomb," the Tribune 19 (1945).

${ }^{[2]}$ Ibid.

${ }^{[3]}$ Friedrich August Hayek, The Road to Serfdom (Psychology Press, 2001).

${ }^{[4]}$ See, e.g., the Paul Kengor. 2014. Dupes: How America's Adversaries Have Manipulated Progressives for a Century. Open Road Media.

[5] Joshua S. Goldstein. 2011. Think Again: War. Foreign Policy 188: 1-9.

${ }^{[6]}$ Kengor, Dupes.

[7] A. Dunst. 2016. Madness in Cold War America: Mad America. Taylor \& Francis. https://books.google.com/books?id=JTQlDwAAQBAJ

${ }^{[8]}$ Richard Wurmbrand. 2017. Tortured for Christ. David C Cook.

${ }^{[9]}$ Steven M. Teles. 2016. 20. How the Progressives Became the Tea Party's Mortal Enemy. The Progressives' Century. New Haven: Yale University Press, pp. 453-477; see, also, C.J. Wolfe. 2011. Lessons from the Friendship of Jacques Maritain with Saul Alinsky. Catholic Social Science Review 16: 229-240.

${ }^{[10]}$ See, e.g., Paul Kengor. 2017. A Pope and a president: John Paul II, Ronald Reagan, and the extraordinary untold story of the 20th century. Open Road Media. See, also, Michael A. Milton. 2013. What Ronald Reagan's Legacy Can Teach Us Today About Religious Liberty. Matthews, NC: Faith for Living, Inc.. https://michaelmilton.org/2014/02/06/what-ronald-reagans-legacy-can-teachus-today-about-religious-liberty/

${ }^{[11]}$ See, e.g., McManus, M. (2005). "How Pope John Paul Fought Communism - by Mike McManus VirtueOnline â The Voice for Global Orthodox Anglicanism." Retrieved April 12, 2021, from https: //virtueonline.org/how-pope-john-paul-fought-communism-mike-mcmanus.

${ }^{[12]}$ Lee Edwards. 2005. John Paul II: Winning the Cold War. Heritage Foundation https://www. heritage. org/commentary/john-paul-ii-winning-the-cold-war .

[13] "ALBANIANS TOPPLE HOXHA'S STATUE." Washington Post, 20 Feb. 1991, p. Online archives, www.washingtonpost.com/archive/politics/1991/02/21/albanians-topple-hoxhas-statue/5f39448c-63d74f61-af66-e758a5488623/. Accessed 25 Apr. 2021.

${ }^{[14]} *$ Father John is a pseudonym.

${ }^{[15]}$ I share *Father John's statement, as best I can recall, the poignant points embedded into my soul; and from my journal notes prepared for World Magazine.

${ }^{[16]}$ Biden integrated American history, Augustine, the Torah, and Christianity to marshal forward support for his statement, "And together, we shall write an American story of hope, not fear. Of unity, not division." See President Joseph R. Biden, Jr. | The White House. "Inaugural Address By President Joseph R. Biden, Jr. | The White House". 2021. The White House. https://www. whitehouse.gov/briefing-room/speechesremarks/2021/01/20/inaugural-address-by-president-joseph-r-biden-jr/.

${ }^{[17]}$ See Hayek on uniformity in F.A. Hayek. "The Great Utopia." In The Road to Serfdom. London: Routledge, 1944, 24. Hayek is quoting Walter Lippmann, "Though they promise themselves a more abundant life, they must in practice renounce it; as the organized direction increases, the variety of ends must give way to uniformity. That is the nemesis of the planned society and the authoritarian principle that is the nemesis 
of the planned society and the authoritarian principle in human affairs." See Atlantic Monthly, November 1936 , p. 552 .

${ }^{[18]}$ I refer to that most pernicious peddler of postmodernity, Michel Foucault (1926-1984). A deconstructionist, Foucault examined power structures, e.g., Christianity, Western Civilization, gender, sought to redefine them, and free them from traditional centers of power. I consider him a moral anarchist whose teachings were enormously successful in permeating Western thought.

\section{Acknowledgements}

I am grateful to the late Zef Nekaj (1919-2003), my professor at the Defense Language Institute (DFLI) who inspired me to study Albanian as a lens into the predictable behavior of global Communist-Socialist regimes and movements. I am indebted to my assistant and friend, Mrs. Christine Hartung, whose able management of my time and commitments allows me to research and write without completely ignoring all else. As always, I am able to minister through all means available because of the love, faithfulness, and encouragement of my wife, Mae. My son, John Michael Milton, a higher education professional in his own right, remains an irreplaceable source of love, wisdom, joy, and critical insight. I pray for "all our children "-Kim, Jessica, Julie, Wayne, Amy, Heather, Matthew, and John Michael — who, with their children, will likely see a world that we will not. We have certain hope that though sin abounds, including the beast of Statism, Grace will abound more. 